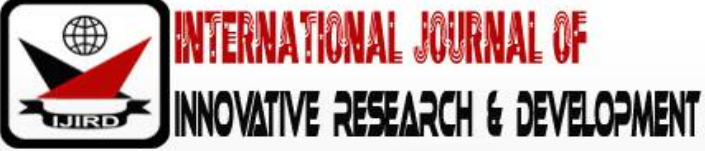

ISSN 2278 - 0211 (Online)

\section{Important Financial Variables Affecting Motivation: A Study of Building Tradesmen in the Nigerian Construction Industry}

\author{
Ogbuiyi Obianuju J. \\ Teacher, Department of Education, \\ Post Primary Schools Services Commission, Awka Anambra State, Nigeria
}

\begin{abstract}
:
Aim: This Study identifies the important financial variables affecting the Motivation of Building Tradesmen in the Nigerian Construction Industry.

Study Design: The study was a survey research. Questionnaires were distributed randomly to tradesmen in selected construction firms in Anambra State, Nigeria.

Place and Duration of the Study: The study was conducted in Anambra State Nigeria and it lasted for a period of five months.

Methodology: A total of 144 questionnaires were distributed to the respondents, out of which 136 were correctly completed, returned and found useful. Data collected were analyzed and presented using tables, mean, percentages, pie charts, bar charts and Relative Important Index (RII)

Results: The study revealed equitable wage as the most important financial variable affecting tradesmen motivation with RII of 0.86 , followed by prompt wage payment $(0.81)$, high wage rate $(0.77)$. The least in their consideration was overtime with pay (0.43). Also, punishment and supervision are the predominant motivational tools used by management of construction companies in the study area.

Conclusion: The study was concluded by recommending that management pay serious attention to the financial variables of motivation especially equitable wage and prompt wage payment. And to also minimize the use of supervision and Punishment as predominant motivational tools for improved work performance and effective project delivery.
\end{abstract}

Keywords: Motivation, types of motivation, financial motivation variables, building tradesmen

\section{Introduction}

Motivation seems to be one of the most important tools of human resource management. Organizations design motivation systems to encourage employees to perform in the most effective way and also to attract potential candidates (Kirstein, 2010). With positive motivation philosophy and practice in place, productivity, quality and service should improve because motivation helps people towards achieving goals, gaining positive perspective, creating the power for change, building self-esteem and capability, and managing their development and helping others (Adjei, 2009).

Motivation refers to the psychological process that gives behaviour a purpose and direction, a predisposition to behave in a purposive manner to achieve specific unmet needs, an unsatisfied need, and the will to achieve respectively (Linder, 1998). Motivation is defined as "the force within a person that affects his or her direction, intensity and persistence of voluntary behaviour" (Mcshane and Von, 2000). Motivation can be divided into three parts. The first part looks at arousal that deals with the drive, or energy behind individuals' action. People tend to be guided by their interest in making a good impression on others, doing interesting work and being successful in what they do. The second part refers to the choice people make and the direction their behaviour takes. The last part deals with maintaining motivated behaviour which clearly defines how long people have to persist at attempting to their goals (Greenberg and Baron, 2000). The word motivation has continued to be defined by more authors in recent times and include: It is concerned with why people do what they do, it starts with a need in human being which creates a vacuum in a person ( Mmadu and Okafor, 2014); Motivation is defined as the processes that account for an individual's intensity, direction, and persistence of efforts towards attaining a goal (iEduNote, 2019); Motivation refers to the reason for people's actions, willingness and goals. It is derived from the word motive which is defined as a need that requires satisfaction. It is one's direction to behaviour, what causes a person to want to repeat behaviour, a set of force that acts behind the motives. (Wikipedia, 2019).

An employee must be motivated towards his role and work in an organization, if no motivation is present in an employee, then that employee's quality of work or overall work performance will deteriorate (Agarwal and Agarwal, 2013). It is important that managers and organizational leaders learn to understand effectively and deal with their 
employee's motivation; since motivated employees are necessary to let the organization being successful in the next century. Unmotivated employees are likely to expend little effort in their jobs, avoid the work place as much as possible, exit the organization and produce low quality of work. In cases that employees are motivated, they help the 0rganizations survive in rapidly changing workplaces (Brent, 2010).

Earnings related factors were predominant for motivating construction operatives in Nigeria, Thus, not only are financial incentives necessary to enhance motivation at personal and organizational levels, but also to promote unified motivation across highly interdependent and contractually fragmented project teams (Olomolaiye and Ogunlana, 1998). Money has continued to be a good motivator for building tradesmen in the Nigerian construction industry (Akinloye and Okhankhuele, 2014; Afuye and Gerryshom, 2016). However, it has been difficult for management to identify the important financial motivational factors that affect their workers' productivity in construction project delivery. On this note, this study attempts to identify the important financial variables affecting the motivation of building tradesmen in the Nigerian construction industry. Particular attention is devoted to types of motivation and the financial motivation variables.

\section{Literature Review}

\subsection{Types of Motivation}

Motivation present in workplace is of two types: intrinsic and extrinsic. Both kinds of motivation take part equally in day-today life of an individual, and there are basic similarities and differences between the two (Shrestha, 2017). Intrinsic motivation stems from the word "internal" which implies motivation comes from within the individual or from the activity itself and positively affects behaviour, performance, and well-being. In other words, this type of motivation is self-generated when intrinsically motivated, the individual will also strive to satisfy three innate psychological needs: namely needs for autonomy, competence, and relatedness while extrinsic motivation refers to motivation that comes from outside an individual in exchange for external rewards and is not derived from the work itself Extrinsic motivation takes the form of tangible monetary or non- monetary incentives such as pay rise, gift certificates, material possessions, vacation trips wall plagues, company banquets, movie tickets and prestige evaluations among others(Deci and Ryan 2000). Intrinsic motivation represents all the things that motivate you based on internal rewards while extrinsic motivation represents all the things that motivate you based on external rewards (Tarver, 2019). Tarver (2019), specified types of intrinsic and extrinsic motivation as follows:

\section{Intrinsic}

- Competence and learning

- Attitude motivation

- Achievement motivation

- Arousal theory of motivation

- Physiological motivation

Extrinsic

- Incentive motivation

- Fear motivation

- Power motivation

- Affiliation and social motivation

- Expectancy theory of motivation

- Equity Theory of motivation

\subsection{Financial Motivational Variables}

Monetary incentives refer to those incentives which satisfy the subordinates by providing them with rewards in terms of money (MSG Experts, 2012). Money is used as a primary outcome in comparison with the employees' input to determine if they are being treated equitably. Money is perceived as helpful in satisfying the social needs by enabling the possession of various material items. Hence, various wage plans and bonus schemes are introduced to motivate and stimulate the people to work. Therefore, money not only satisfies psychological needs but also the security and social needs. Money is important to employees because it is a medium of exchange (Odendaal and Roodt, 2003). Odendaal and Roodt (2003) postulate that for money to motivate an individual's performance, certain conditions must be met: Firstly, money must be important to the individual. Secondly, money must be perceived by an individual as being a direct reward for performance. Thirdly, the marginal amount of money offered for the performance must be perceived by the individual as being significant; fourthly, management must have the discretion to reward higher performers with more money.

\section{Methodology}

The study is carried out in Anambra State, Nigeria, using a survey method. The name Anambra state was derived from the Anambra River (Omambala) which flows through the area and is a tributary of the River Niger. Anambra state is located between latitudes $05^{\circ} 40^{\prime} \mathrm{N}$ and $07010^{\prime} \mathrm{N}$ and $06^{\circ} 5^{\prime} \mathrm{E}$ and $00^{\circ} 20^{\prime} \mathrm{E}$ (see fig. 1 and 2). The state shares boundaries with Delta to the West, Imo to the South, Enugu to the East and Kogi to the North. It has a total land mass of 4,416 km and situated on the Eastern side of River Niger. The state has 177 communities (towns) in 21 Local Government Areas. It comprises of three major towns namely; Awka, its capital city, and the seat of Government, the commercial town of Onitsha and the industrial city of Nnewi. According to the NPC (2006) Anambra State has a population 4, 182, 032 made up of 2,007,391 and males 2,174, 64 females, which makes it the most populous state nationwide. It also has estimated average population density 1500 - 2000 persons per square kilometre, making it the second most densely populated state 
in Nigeria, after Lagos state. With an annual population growth rate of 2.21 percent per annum, Anambra has over $60 \%$ of its people living in urban area making it one of the most urbanized places in Nigeria.

Anambra state is in the tropical zone of Nigeria, with the distinct seasons, dry and rainy seasons from December to April and May to October respectively while annual precipitation ranges from $15000 \mathrm{~mm}$ to $2000 \mathrm{~mm}$ rainfall with July as the rainiest month. According to him, humidity is relatively high between 65 - 80\% throughout the year; daily temperatures up to $25^{\circ} \mathrm{C}$ are recorded on very hot days in January and March. Anambra state has fairly good subsoil strata. It exhibit quality sub base foundation soil for buildings and construction work: extensive construction activities and concentration of industry participants such as clients, contractors and professional consultants are found in the state capital of Awka and other commercial towns such as Onitsha and Nnewi. The contribution of the construction industry over the past few years represents a significant percentage of the state Gross Domestic Product (GDP). Construction activities also provide a substantial source of employment, especially unskilled labour.

The population of this study constitutes of tradesmen (Masons, Carpenters and steel fitters) engaged by seven construction companies located in the state. The population of these tradesmen as obtained from their various companies is 225 (see table 1)

Taro Yamane sample size method is employed to determine the appropriate sample size for the study. Taro's formula is represented as:

$\mathrm{n}=\frac{N}{1+N(e) 2}$

Where " $\mathrm{n}$ " is the sample size, " $\mathrm{N}$ " is the population (225) and " $\mathrm{e}$ " is the level of confidence (i.e. 95\%).

Thus, the sample size

$\mathrm{n}=\frac{225}{1+225(0.05) 2}$

$=144$

Data were collected through structured questionnaire administered to selected respondents. Accordingly, out of a total 144 questionnaire administered, only 136 are returned, completed and found useful.

Consequently, table; mean; percentage; histogram and pie chart are used for data presentation. However, Relative Important Index (RI) was used for ranking and computed using the formula:

$\mathrm{RII}=\frac{\sum F X}{A * N}$

Where,

$\sum F X=$ Weight given to each statement by respondents and ranges 1-5

$\mathrm{A}=$ Higher Response Integer

$\mathrm{N}=$ Total Number of Respondents

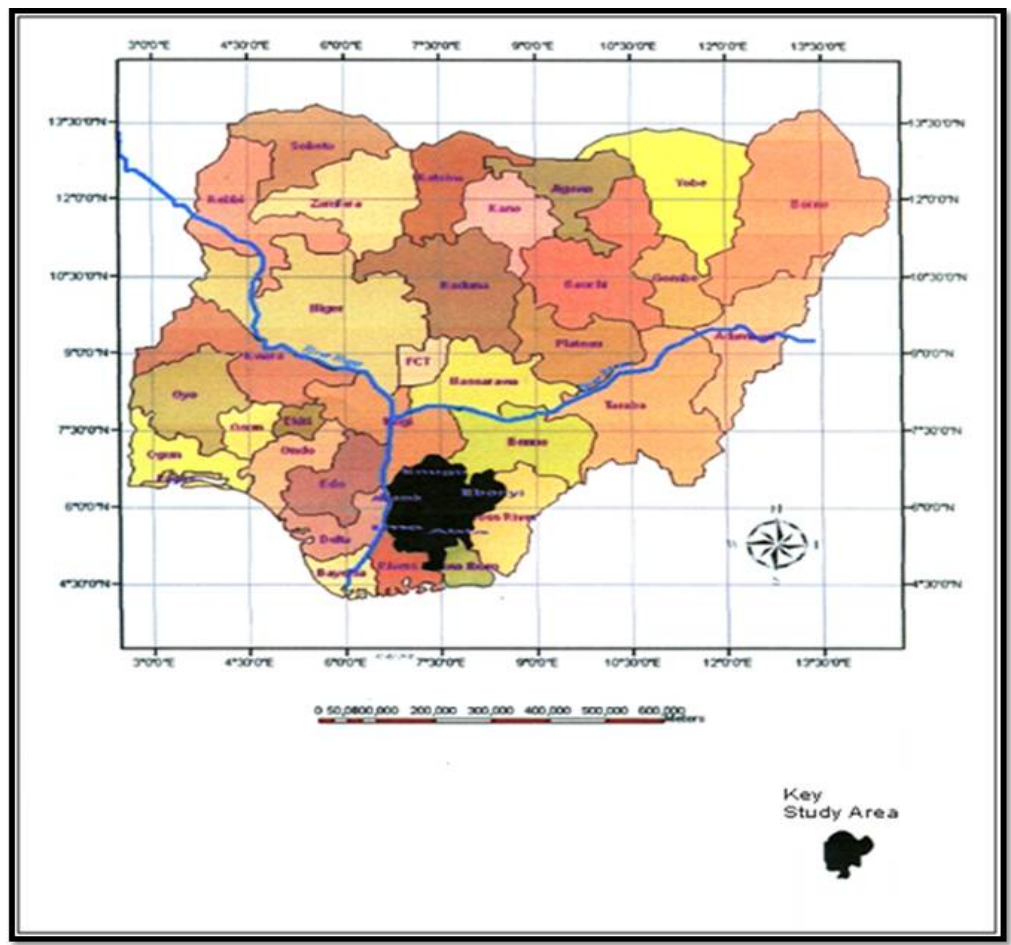

Figure 1: Map of Nigeria Showing South East Nigeria (Study Area)

Source: National Space Research and Development Agency 


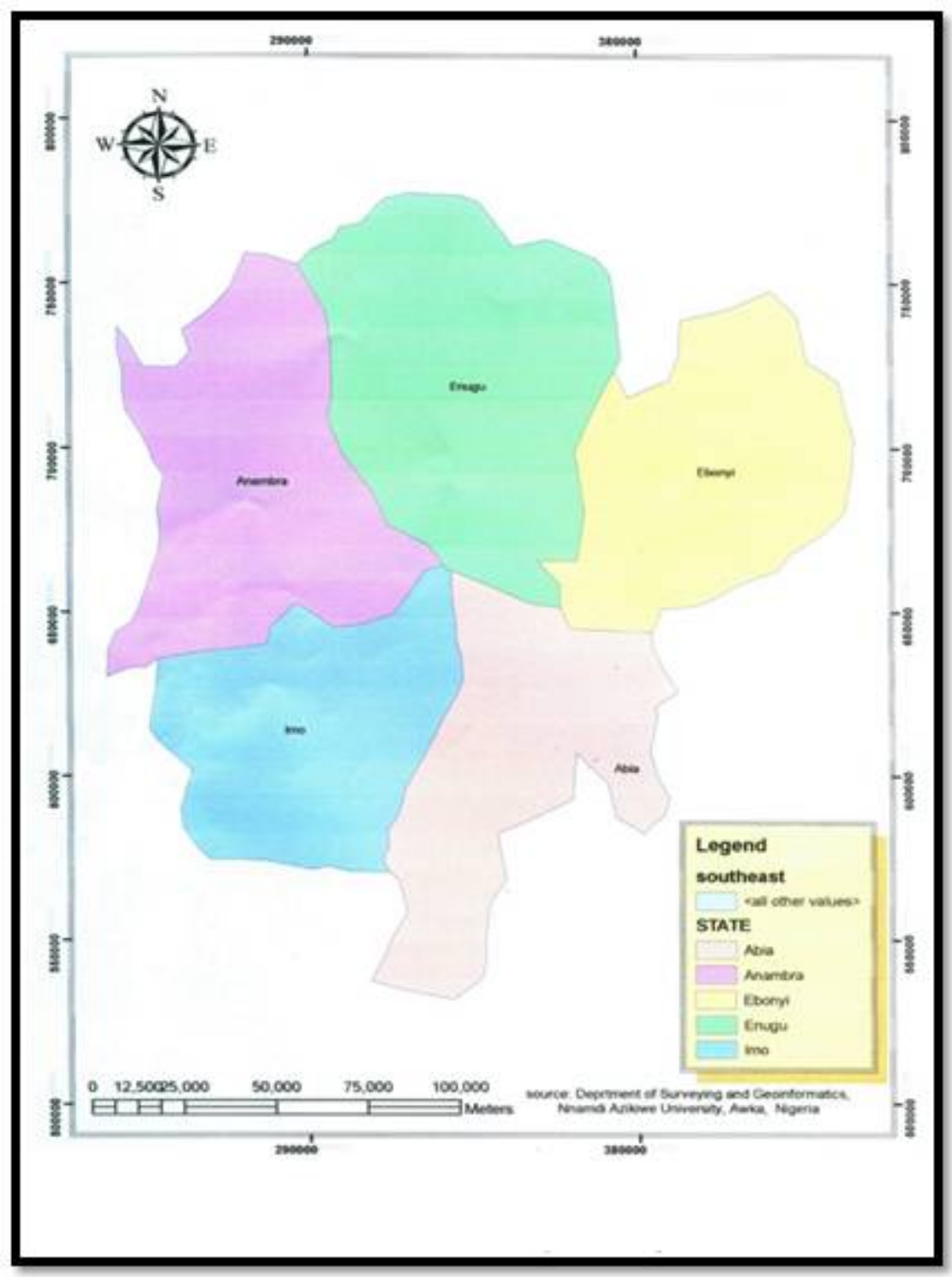

Figure 2: Map of South East Niagara the Five States Source: Development of Surveying and Geoinformatics Nnamdi Azikiwe University, Awka, Nigeria

\section{Result and Discussion}

The descriptive result in table 3 shows that the most important financial motivation variable to the tradesmen is; equitable wage which ranked first (0.86), followed by prompt wage payment (0.81) and high wage rate (0.77).These were also followed by cash award, allowances and end of the year bonus, RII $(0.67,0.54,0.50)$ respectively. The least in their consideration is overtime with pay (0.43).

Table 4 shows that supervision ranked first among the motivational techniques used by companies (0.89), followed by punishment (0.73) and financial reward outside wage (0.72). These were followed by break at work $(0.53)$, job security (0.53), and training (0.46). The lowest in the least is promotion $(0.36)$.

Table 5 discloses that productive tradesman ranked first concerning the effect of financial motivation on work behaviour (0.88), followed by committed tradesman (0.78) and happy tradesman (0.64). These were followed by good quality of work, reduced rework and refusal to quit from company, RII $(0.57,0.54,0.53)$ respectively. The lowest in the list is working overtime (0.37).

Figure 3 shows a bar chart on the population distribution of the respondents as represented in table 1, while figure 4 discloses the distribution of questionnaire to the respondents as shown in table 2 .

\begin{tabular}{|c|c|c|c|}
\hline S/ N & Tradesmen & Population & Sample Size \\
\hline 1 & Mason & 112 & 72 \\
\hline 2 & Carpenter & 66 & 42 \\
\hline 3 & Steel Fitter & 47 & 30 \\
\hline & Total & 225 & 144 \\
\hline
\end{tabular}

Table 1: Population Distribution of the Respondents 


\begin{tabular}{|c|c|c|}
\hline Questionnaire & Frequency & Percentage \\
\hline Number of questionnaire returned & 8 & 5.56 \\
\hline Number of questionnaire returned not returned & 136 & 94.44 \\
\hline Total & 144 & 100 \\
\hline
\end{tabular}

Table 2

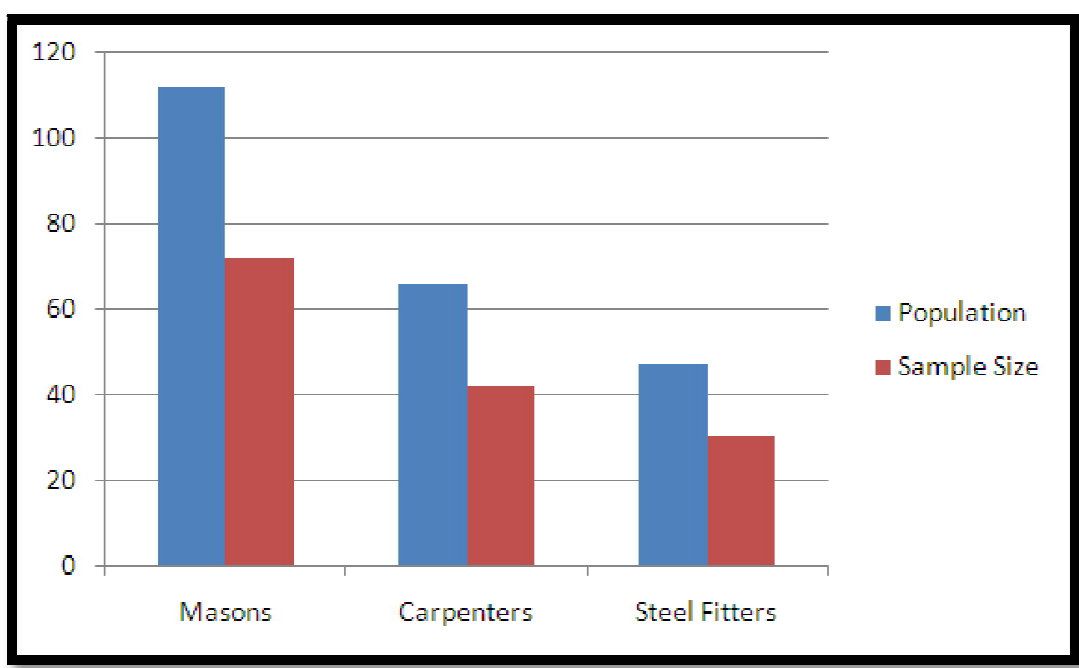

Figure 3: Population distribution of the respondents Source: Researcher's field survey

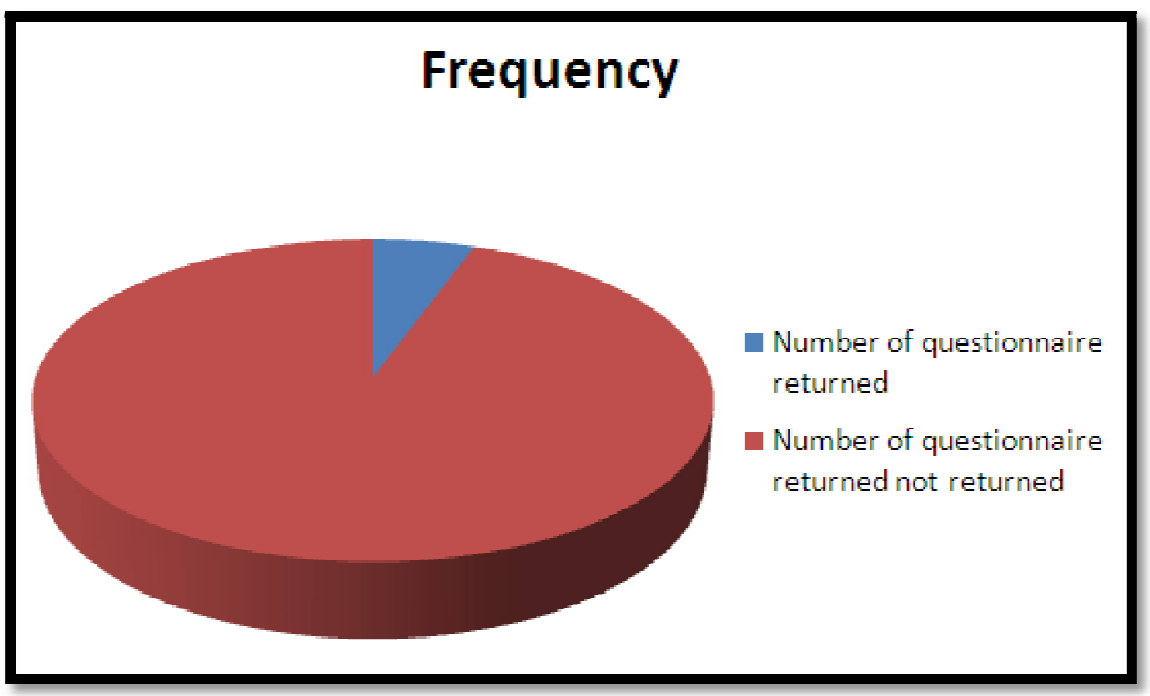

Figure 4: Pie Chart Showing Distribution of Questionnaire Source: Researcher's Field Survey

\begin{tabular}{|c|c|c|c|c|c|c|c|c|c|c|c|}
\hline \multirow[t]{2}{*}{$\mathbf{S} / \mathbf{N}$} & \multirow{2}{*}{$\begin{array}{c}\text { Financial } \\
\text { Motivational } \\
\text { variables }\end{array}$} & \multicolumn{5}{|c|}{ Frequency } & \multirow[t]{2}{*}{$\sum F$} & \multirow[t]{2}{*}{$\sum F X$} & \multirow[t]{2}{*}{$\overline{\mathrm{X}}$} & \multirow[t]{2}{*}{ RII } & \multirow[t]{2}{*}{ Rank } \\
\hline & & 5 & 4 & 3 & 2 & 1 & & & & & \\
\hline 1 & Cash award & 42 & 36 & 12 & 19 & 27 & 136 & 455 & 3.35 & 0.67 & 4th \\
\hline 2 & End of the year bonus & 24 & 17 & 25 & 9 & 61 & 136 & 342 & 2.51 & 0.50 & 6th \\
\hline 3 & Financial allowances & 23 & 20 & 2 & 72 & 19 & 136 & 364 & 2.68 & 0.54 & 5 th \\
\hline 4 & Overtime with pay. & 7 & 26 & 11 & 31 & 61 & 136 & 295 & 2.17 & 0.43 & 7th \\
\hline 5 & $\begin{array}{l}\text { Prompt wage } \\
\text { payment }\end{array}$ & 70 & 21 & 28 & 15 & 2 & 136 & 550 & 4.04 & 0.81 & 2nd \\
\hline 6 & High wage rate & 47 & 39 & 32 & 16 & 2 & 136 & 521 & 3.83 & 0.77 & $3 \mathrm{rd}$ \\
\hline 7 & Equitable wage & 81 & 29 & 20 & 0 & 6 & 136 & 587 & 4.32 & 0.86 & Ist \\
\hline
\end{tabular}

Table 3: Tradesmen Response on the Important Financial Variables Affecting Motivation

5. Most Important; 4. Very Important, 3. Important, 2. Not Important; 1. Not Important At All 


\begin{tabular}{|c|c|c|c|c|c|c|c|c|c|c|c|}
\hline \multirow[t]{2}{*}{$\mathbf{S} / \mathbf{N}$} & \multirow{2}{*}{$\begin{array}{c}\text { Company's Motivation } \\
\text { Technique }\end{array}$} & \multicolumn{5}{|c|}{ Frequency } & \multirow[t]{2}{*}{$\sum F$} & \multirow[t]{2}{*}{$\sum F X$} & \multirow[t]{2}{*}{$\bar{X}$} & \multirow[t]{2}{*}{ RII } & \multirow[t]{2}{*}{ Rank } \\
\hline & & 5 & 4 & 3 & 2 & 1 & & & & & \\
\hline 1 & Supervision & 84 & 28 & 24 & 0 & 0 & 136 & 604 & 4.44 & 0.89 & 1 st \\
\hline 2 & Punishment & 47 & 41 & 29 & 14 & 5 & 136 & 494 & 3.63 & 0.73 & 2nd \\
\hline 3 & Training & 27 & 17 & 25 & 29 & 38 & 136 & 312 & 2.29 & 0.46 & 6th \\
\hline 4 & $\begin{array}{l}\text { Financial reward outside } \\
\text { wage }\end{array}$ & 43 & 39 & 20 & 27 & 7 & 136 & 492 & 3.62 & 0.72 & $3 r d$ \\
\hline 5 & Recognition & 6 & 28 & 14 & 34 & 54 & 136 & 302 & 2.22 & 0.44 & 7th \\
\hline 6 & Break at work & 26 & 19 & 27 & 12 & 52 & 136 & 363 & 2.67 & 0.53 & 4th \\
\hline 7 & $\begin{array}{l}\text { Involvement in decision } \\
\text { making }\end{array}$ & 2 & 20 & 12 & 36 & 66 & 136 & 264 & 1.94 & 0.39 & 8th \\
\hline 8 & Job security & 26 & 19 & 29 & 7 & 55 & 136 & 362 & 2.66 & 0.53 & 4 th \\
\hline 9. & Promotion & 2 & 19 & 5 & 34 & 76 & 136 & 245 & 1.80 & 0.36 & 9th \\
\hline
\end{tabular}

Table 4: Tradesmen response on the Motivational Techniques used in their Companies 5. Used all the time; 4 used most of the time; 3; Used sometimes; 2. Rarely used; 1 . Not used at all

\begin{tabular}{|c|c|c|c|c|c|c|c|c|c|c|c|}
\hline \multirow[t]{2}{*}{$\mathbf{S} / \mathbf{N}$} & \multirow{2}{*}{$\begin{array}{c}\text { Company's Motivation } \\
\text { Technique }\end{array}$} & \multicolumn{5}{|c|}{ Frequency } & \multirow[t]{2}{*}{$\sum \mathrm{F}$} & \multirow[t]{2}{*}{$\sum \mathrm{FX}$} & \multirow[t]{2}{*}{$\bar{X}$} & \multirow[t]{2}{*}{ RII } & \multirow[t]{2}{*}{ Rank } \\
\hline & & 5 & 4 & 3 & 2 & 1 & & & & & \\
\hline 1 & Happy tradesman & 30 & 28 & 37 & 23 & 18 & 136 & 437 & 3.21 & 0.64 & 3rd \\
\hline 2 & Committed tradesman & 49 & 44 & 30 & 10 & 3 & 136 & 534 & 3.92 & 0.78 & 2 nd \\
\hline 3 & Productive tradesman & 82 & 29 & 24 & 1 & 0 & 136 & 600 & 4.41 & 0.88 & 1st \\
\hline 4 & Good quality of work & 27 & 24 & 29 & 14 & 42 & 136 & 388 & 2.85 & 0.57 & 4th \\
\hline 5 & Reduced rework & 27 & 19 & 30 & 7 & 53 & 136 & 368 & 2.71 & 0.54 & 5 th \\
\hline 6 & Refusal to quit from work & 26 & 15 & 23 & 30 & 42 & 136 & 361 & 2.65 & 0.53 & 6th \\
\hline 7 & Working overtime & 3 & 19 & 7 & 34 & 73 & 136 & 253 & 1.86 & 0.37 & 7th \\
\hline
\end{tabular}

Table 5: Tradesmen Response on the Effect of Financial Motivation Variables on Work Attitude

\section{Strongly Agree; 4. Agree; 3. Not Certain; 2. Disagree; 1. Strongly Disagree}

\section{Conclusion and Recommendation}

Building tradesmen react positively to financial variables of motivation. But, among these variables, the most important to them is equitable wage which ensures that their job performances are and their qualities are linked to their wage. Their quality being expressed through their years of experience, expertise and level of academic qualification. They also want the payment to be made on time and for their payment to be high as well. Outside their wage, they equally value any allowance that management offers to them. Although construction companies use financial reward outside wage to motivate their tradesmen, supervision and punishment are predominant.

It is recommended that:

- Construction companies pay serious attention to the use of financial motivational variables especially equitable wage and prompt wage payment in addition to allowances in order to keep their work force motivated.

- Minimize the use of punishment and supervision as predominant motivational techniques.

- Refer to wage tariff or wage coefficients used in public service for the calculation of equitable wage for each grade of their tradesmen.

Thus, if serious attention is paid to the use of financial variables of motivation for the tradesmen in the study area especially the most significant ones revealed by this study, it will go a long way in keeping the tradesmen motivated. Keeping them motivated will result in improved productivity, commitment and good quality of work. All these will result in effective project delivery for companies in the area as well as boost the reputation of the company thereby enabling them to have a competitive advantage.

\section{References}

i. Mmaduka, C.E. and Okafor, O. (2014). Effect of Motivation on Employee Productivity: A study of manufacturing Companies' in Nnewi. International Journal of Managerial Studies and Research. 2 (7), 137.

ii. Afuye, F., Sammy, L. and Gerryshom, M. (2016). Impact of Motivation on Productivity of Craftsmen in Construction firms in Lagos, Nigeria. International Journal of Economics and Finance. 8 (4), 274.

iii. Akinloye, F.L. and Okhankhuele, T.M. (2014). The Effect of Motivation on Project

iv. Execution in Nigeria: A case study of Bayelsa Plastic Industry, Yenagoa, Bayelsa state, Nigeria. British Journal of Applied Science and Technology 4 (21), 2994. 
v. Shrestha, P. (2017). Types of Motivation: Intrinsic and Extrinsic Motivation," in Psychology.Online. Retrieved from:http/ / www.psychestudy.com/ general/ motivationemotion/ types-motivation.(Accessed, September 2019).

vi. Tarver, E. (2019). 11 Types of Motivation: What they are and how to use them. Online.

vii. Retrieved from: http/ / www.evantarver.com. (Accessed, September 2019).

viii. Wikipedia (2019). Motivation. Online. Retrieved from: http// n.mwikipedia.org.

ix. (Accessed, September 2019).

x. iEduNote (2017). What is Motivation? Definition, Features, Objectives. Online.

xi. Retrieved from: http/ / iedunote.com/ motivation. (Accessed, September 2019).

xii. Department of Surveying and Geoinformatics (2018). Map of South East Nigeria showing Anambra State. Awka, Ugochukwu.

xiii. National Space Research and Development Agency (2014). Map of Nigeria showing the

xiv. South East. Awka, Ezeokonkwo.

xv. Adjei, E.A (2009). Motivational Strategies to Improve Productivity in the Construction Industry in Ghana. An Msc. Thesis submitted to the Department of Building Technology, Kwameh Nkrumah University of Science and Technology, Kumasi.

xvi. Agarwal, S. and Agarwal, K. (2013). Motivation- An Important key to improve Employee Performance. International Journal of commerce, Business and Management, 2(6), 437.

xvii. Deci, E.L., Ryan, R.M., 1985. Intrinsic Motivation and Self-determination in Human Behavior. Plenum: New York.

xviii. Kirstein, m. (2010). The role of motivation in Human Resource Management: Importance of Motivation Factors among future business persons. Msc. Thesis submitted to Aarhus School of Business, Aarhus University.

xix. Linder, J.R. (1998). Understanding Employee’s Motivation. Journal of Extension (3), 5-6.

xx. MSG Experts. (2012). Organisational Behaviour. Online. Retrieved from: http:// www.managementstudyguide.com/ what is motivation.htm.(Accssd March, 2017).

xxi. Odendaal, A. and Roodt, G. (2003). Basic Motivation Concepts. In: Robbins, S.P., Odendaal, A. and Roodt, G. (eds.). Organisational Behaviour - Global and Southern African Perspectives, Cape Town, Pearson Education.

xxii. Olomalaiye, P.O. (1988). An Evaluation of bricklayers' motivation and productivity. A PhD dissertation submitted to Loughborough University of Technology.

xxiii. McShane, S.L and Von Glinow, M.A (2000). Organizational behavior, McGraw Hill: Irwin.

xxiv. Brent, K. (2010). Employee Motivation and Performance: Organization and Strategy. Bsc. Thesis submitted to Tilburg University.

xxv. Greebberg, J. and Baron, R.A (2000). Behaviour in Organizations. 7.ed., Prentice Hall: Newjersy. 